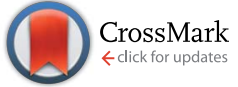

Cite this: RSC Adv., 2017, 7, 10407

Received 18th November 2016 Accepted 2nd February 2017

DOI: $10.1039 / c 6 r a 26983 d$

rsc.li/rsc-advances

\section{Reductive removal of gaseous nitrous oxide by activated carbon with metal oxide catalysts}

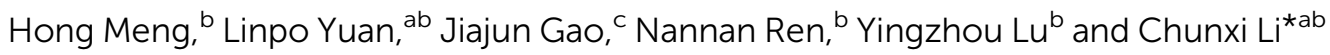

The efficient reductive decomposition of gaseous nitrous oxide $\left(\mathrm{N}_{2} \mathrm{O}\right)$ from industrial effluents is of practical importance in abating greenhouse gas emissions. In the present study, active carbon (AC) has been chosen as both a reductive agent and a catalyst support. Dozens of AC-based catalysts with different kinds and amounts of metal oxide have been prepared under various conditions and characterized. The performances of $\mathrm{Cu}$-containing $\mathrm{AC}$ have been studied at varying gas flow rates, $\mathrm{Cu}$ contents, and calcination temperatures. $\mathrm{N}_{2} \mathrm{O}$ in a gas mixture $\left(42 \% \mathrm{~N}_{2} \mathrm{O}, 58 \% \mathrm{~N}_{2}\right)$ was found to be completely removed by $\mathrm{Cu}$-loaded $\mathrm{AC}\left(9 \mathrm{wt} \% \mathrm{Cu}\right.$, calcined at $400{ }^{\circ} \mathrm{C}$ ) at $325^{\circ} \mathrm{C}$ with a GHSV of $2293 \mathrm{~h}^{-1}$. This process is viable by virtue of the low cost of $A C$ and easier manipulation and process control in comparison with alternative methods employing reductive gases such as hydrogen and ammonia.
\end{abstract}

\section{Introduction}

Nitrous oxide $\left(\mathrm{N}_{2} \mathrm{O}\right)$ is a greenhouse gas with a global warming potential value of about 310 . As a by-product of the manufacture of several chemical products, such as adipic acid and nitric acid, its atmospheric concentration has increased significantly over the last decades, and continues to increase by $0.2-0.3 \%$ per year. ${ }^{1}$ This inexorable trend has attracted a great deal of attention for the development of an efficient method for the removal of $\mathrm{N}_{2} \mathrm{O}$ from industrial exhausts, especially for the tail gas of the adipic acid production process using $\mathrm{HNO}_{3}$ as oxidizing agent, where the $\mathrm{N}_{2} \mathrm{O}$ content is as high as $38 \%$ along with $\mathrm{N}_{2} 48.1 \%, \mathrm{O}_{2} 4.4 \%, \mathrm{CO}_{2} 9.5 \%$, and $\mathrm{NO}$ $0.03 \%$ (in wt $\%)^{2}$

A direct decomposition process is generally used for gas effluents with low $\mathrm{N}_{2} \mathrm{O}$ concentrations, ${ }^{3}$ which operates at high temperatures $\left(>500^{\circ} \mathrm{C}\right)$ with various catalysts, e.g., hydrotalcitelike materials, ${ }^{4}$ metal-containing zeolites, ${ }^{5-7}$ or supported metal oxides, ${ }^{8-11}$ e.g. $\mathrm{CaO}-\mathrm{Co}_{3} \mathrm{O}_{4},{ }^{12}$ and $\mathrm{NiLaO}_{x} \cdot{ }^{13}$ The decomposition of $\mathrm{N}_{2} \mathrm{O}$ is composed of three steps, viz., adsorption, cleavage of the $\mathrm{N}-\mathrm{O}$ bond, and desorption of $\mathrm{O}_{2}$, of which the desorption of $\mathrm{O}_{2}$ is considered as the rate-limiting step. To promote $\mathrm{O}_{2}$ desorption, some reductive substances, e.g., $\mathrm{CH}_{4}, \mathrm{NH}_{3},{ }^{14} \mathrm{H}_{2},{ }^{15}$ and $\mathrm{CO},{ }^{16}$ have been used to instantly consume the in situ generated $\mathrm{O}_{2}$. However, these reductive gases are expensive and/ or explosive, and their flow rate needs dynamic control

${ }^{a}$ State Key Laboratory of Chemical Resource Engineering, Beijing University of Chemical Technology, Beijing 100029, P. R. China. E-mail: licx@mail.buct.edu.cn; Fax: +8610 64410308; Tel: +861064410308

${ }^{b}$ College of Chemical Engineering, Beijing University of Chemical Technology, Beijing 100029, P. R. China

${ }^{c}$ School of Chemical Engineering and Pharmacy, Wuhan Institute of Technology, Wuhan 430205, P. R. China according to the composition of the gas stream, which complicates the process. Activated carbon (AC), as an inexpensive and active solid reducing agent, can overcome these drawbacks, and is thus worthy of study for the reductive removal of $\mathrm{N}_{2} \mathrm{O}$. In fact, coal char is effective in reducing $\mathrm{N}_{2} \mathrm{O}$ and $\mathrm{NO}$ to $\mathrm{N}_{2}$ at combustion temperature, ${ }^{17}$ and $\mathrm{AC}$ loaded with alkali metal oxides shows better performance. Both $\mathrm{Na}$ and $\mathrm{K}$ can catalyze the reaction between carbon and $\mathrm{N}_{2} \mathrm{O}$, and $\mathrm{K}$ is better than $\mathrm{Na}^{18,19}$ The reaction between $\mathrm{N}_{2} \mathrm{O}$ and $\mathrm{C}$ may also be catalyzed by $\mathrm{Ni}$ and $\mathrm{Pt}$, and further promoted by $\mathrm{K}$, as reported by Gonçalves $e t$ al. ${ }^{20,21}$

To date, little research has been conducted to compare the performances of different metal oxides supported on AC for the removal of $\mathrm{N}_{2} \mathrm{O}$ under otherwise identical conditions. In this paper we are focused on the treatment of the tail gas of adipic acid production process through catalytic reduction of $\mathrm{N}_{2} \mathrm{O}$ using AC as a solid reducing agent. For this purpose, we made a comparative study on the catalytic performances of different metal oxides for the reduction of $\mathrm{N}_{2} \mathrm{O}$ on $\mathrm{AC}$, and $\mathrm{CuO}$ is found to be the most efficient one. Based on catalyst characterization, a structure-activity relationship has been elucidated, and a reaction mechanism is proposed.

\section{Experimental}

\subsection{Chemical materials}

The AC used was a commercial coconut-shell-derived carbon (Tangshan Hua Neng Technology Carbon Co., Ltd., Tangshan, China). All metal nitrates, i.e. $\mathrm{Cu}\left(\mathrm{NO}_{3}\right)_{2} \cdot 3 \mathrm{H}_{2} \mathrm{O}, \mathrm{Ce}\left(\mathrm{NO}_{3}\right)_{3} \cdot 6 \mathrm{H}_{2} \mathrm{O}$, $\mathrm{Ni}\left(\mathrm{NO}_{3}\right)_{2} \cdot 6 \mathrm{H}_{2} \mathrm{O}, \mathrm{Zn}\left(\mathrm{NO}_{3}\right)_{2} \cdot 6 \mathrm{H}_{2} \mathrm{O}, \mathrm{Co}\left(\mathrm{NO}_{3}\right)_{2} \cdot 6 \mathrm{H}_{2} \mathrm{O}, \mathrm{Fe}\left(\mathrm{NO}_{3}\right)_{3} \cdot 9 \mathrm{H}_{2} \mathrm{O}$, and $\mathrm{Mn}\left(\mathrm{NO}_{3}\right)_{2}$, were of analytical reagent grade (Beijing Chem. Co., Ltd., Beijing, China, purity $\geq 99.0 \%$ ) and were used as received. All aqueous solutions were prepared with deionized water. 


\subsection{Pre-treatment of $\mathrm{AC}$}

The AC was firstly ground into particles of 10-20 mesh, boiled with deionized water for $15 \mathrm{~min}$, and then washed five times with deionized water. The resultant particles were placed in an oven and dried at $110{ }^{\circ} \mathrm{C}$ for $24 \mathrm{~h}$.

\subsection{Preparation of AC-supported metal oxide catalysts}

Certain amounts (0.1-11 wt\%, mass fraction of metal atom in AC) of metal nitrate were weighed and dissolved in water $(300$ $\mathrm{mL}$ ), AC (30 g) was added to each metal nitrate solution, and the mixtures were stirred magnetically for $24 \mathrm{~h}$ at room temperature. They were then placed in an oven and dried at $90{ }^{\circ} \mathrm{C}$ for $72 \mathrm{~h}$ until the water had completely evaporated. The resultant AC was transferred to a muffle furnace and calcined at 200, 300, or $400{ }^{\circ} \mathrm{C}$ for $2 \mathrm{~h}$. Hereinafter, the obtained catalysts are designated as $x \mathrm{M}$-AC- $T$, where $\mathrm{M}$ represents the supported metal, $x$ is the mass fraction of metal atoms in the AC, and $T$ is the calcination temperature.

\subsection{Catalyst characterization}

Fourier-transform infrared (FTIR) spectra in the range $\nu=4000$ $400 \mathrm{~cm}^{-1}$ were recorded at room temperature on a Nicolet 6700 spectrometer. Spectra were collected after 32 scans at $4 \mathrm{~cm}^{-1}$ resolution. The spectra were acquired from $\mathrm{KBr}$ pellets composed of $1 \mathrm{mg}$ of the samples and $100 \mathrm{mg}$ of $\mathrm{KBr}$ dried at $200{ }^{\circ} \mathrm{C}$ for $24 \mathrm{~h}$. X-ray diffraction (XRD) patterns of the calcined samples were recorded at room temperature on a D/Max 2500 (VB2+ PC) diffractometer using $\mathrm{Cu}-\mathrm{K}_{\alpha}$ radiation, operated at 40 $\mathrm{kV}$ and $200 \mathrm{~mA}$. The patterns were recorded over a $2 \theta$ range of $10-90^{\circ}$ with a $0.02^{\circ}$ step size. Simultaneous thermogravimetric analysis (TGA) and derivative thermogravimetric analysis curves were recorded on a TGA/DSC1/1100 SF apparatus at a heating rate of $10{ }^{\circ} \mathrm{C} \min ^{-1}$ over the range $25-700{ }^{\circ} \mathrm{C}$ in air. X-ray photoelectron spectroscopy (XPS) spectra were recorded on an ESCALAB 250 apparatus with a scanning electron spectroscopy for chemical analysis (ESCA) microscope equipped with an Al monochromatic X-ray source $(300 \mathrm{~W})$, employing a beam diameter of $2 \mathrm{~mm}$ in CAE analyzer mode. All binding energies were referenced to the $\mathrm{C} 1 \mathrm{~s}$ peak at $285 \mathrm{eV}$. The individual components were obtained by curve fitting.

\section{5 $\quad \mathrm{N}_{2} \mathrm{O}$ removal experiments}

A stainless steel tubular reactor of $\Phi_{5}$ (i.d.) $\times 650 \mathrm{~mm}$ (effective length $200 \mathrm{~mm}$ ) was used to investigate the activity of metal oxides supported on AC for $\mathrm{N}_{2} \mathrm{O}$ removal at atmospheric pressure. Catalyst $(2.0 \mathrm{~g}$ ) was loaded into the reactor each time, and the gas mixture $\left(42 \% \mathrm{~N}_{2} \mathrm{O}, 58 \% \mathrm{~N}_{2}\right)$ was fed at rates varying from

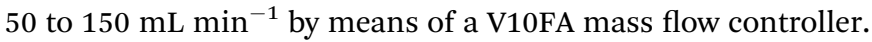
The reaction temperature was controlled through a proportion integral derivative (PID)-regulated oven. To compare the catalytic performances of different transition metal oxides, the reaction temperature was varied from 300 to $550{ }^{\circ} \mathrm{C}$ in steps of $50{ }^{\circ} \mathrm{C}$. To study the effect of the $\mathrm{Cu}$-loading on the performance of the AC-supported $\mathrm{Cu}$ catalysts, the reaction temperature was varied from 300 to $550{ }^{\circ} \mathrm{C}$ in steps of $25{ }^{\circ} \mathrm{C}$. Furthermore, the reaction temperature was varied from 150 to $325{ }^{\circ} \mathrm{C}$ in steps of $25{ }^{\circ} \mathrm{C}$ to evaluate the activities of the catalysts calcined at different temperatures. In all of the experiments, temperature was increased at a rate of $5{ }^{\circ} \mathrm{C} \mathrm{min}^{-1}$. At any given temperature, the reaction duration was $1 \mathrm{~h}$. The concentration of $\mathrm{N}_{2} \mathrm{O}$ in the outlet gas was monitored online by means of a TM GC7700 gas chromatograph equipped with a TCD and a Porapak Q $(6 \mathrm{~m} \times 3$ $\mathrm{mm}$ ) column.

\section{Results and discussion}

\subsection{Characterization of the catalysts}

Structural characteristics of AC. The AC support used here is a coconut-shell-derived carbon material, which is commercially available. Its structure has been characterized by many researchers ${ }^{22-24}$ using $\mathrm{N}_{2}$ adsorption-desorption method, and the structural parameters were determined as follows, i.e. BET specific area $797 \pm 45 \mathrm{~m}^{2} \mathrm{~g}^{-1}$, pore size $2.03 \pm 0.07 \mathrm{~nm}$, and total pore volume $0.402 \pm 0.02 \mathrm{~m}^{3} \mathrm{~g}^{-1}$. Obviously, the AC has a larger pore volume and specific area with rich porosity and micropores, which is much higher than that of coal chars and comparable with many commercial AC sorbents. ${ }^{25-27}$ The pore size and surface area is known to be instrumental for the mass transfer and reactivity for a heterogeneous reaction, and a higher surface area and porosity is helpful for enhancing the dispersion of the catalysts and accessibility of the AC and thus the reduction rate of $\mathrm{N}_{2} \mathrm{O}$. In short, higher surface area favors the catalytic reactivity of $\mathrm{N}_{2} \mathrm{O}$ reduction on AC.

FTIR characterization. FTIR spectra of the pristine AC and metal-oxide-loaded AC samples are shown in Fig. 1. All samples showed an absorption at $\nu \approx 3435 \mathrm{~cm}^{-1}$, which could be ascribed to the stretching vibration of $\mathrm{O}-\mathrm{H}^{28,29}$ due to the presence of water. The water contents of all samples were similar, except for AC-supported $\mathrm{Cu}\left(\mathrm{NO}_{3}\right)_{2}$, as evidenced by the similar intensities of their $\mathrm{O}-\mathrm{H}$ peaks. Furthermore, all of the samples showed two bands centered at $\nu=2921$ and $2852 \mathrm{~cm}^{-1}$ due to asymmetric and symmetric $\mathrm{C}-\mathrm{H}$ stretching vibrations in aliphatic $\mathrm{CH}, \mathrm{CH}_{2}$, and $\mathrm{CH}_{3}$ groups. ${ }^{29,30}$ A scissor vibration of a $\mathrm{CH}_{2}$ group is responsible for an absorption peak at $\nu=1455 \mathrm{~cm}^{-1}$, which was no longer seen for the metal-oxide-loaded AC samples. For ACsupported $\mathrm{Cu}\left(\mathrm{NO}_{3}\right)_{2}$, two bands were seen at $\nu=1383$ and $1340 \mathrm{~cm}^{-1}$ attributable to nitrate $\left(\nu=1410-1340 \mathrm{~cm}^{-1}\right),{ }^{30}$ which disappeared in the calcined ACs. From the above results, we can deduce that: (1) all nitrates were decomposed to the corresponding metal oxides upon calcination at $400{ }^{\circ} \mathrm{C}$; (2) the structural change of AC is virtually irrelevant to the metal species.

Fig. 2 shows the FTIR spectra of Cu-loaded AC samples calcined at 200,300 , and $400{ }^{\circ} \mathrm{C}$, respectively. It is evident that the loaded $\mathrm{Cu}\left(\mathrm{NO}_{3}\right)_{2}$ was completely converted to $\mathrm{CuO}$ in all of the calcined samples.

XRD characterization. The XRD patterns of the pristine and metal-oxide-loaded AC samples are shown in Fig. 3. The pristine AC showed two broad peaks, viz. at $2 \theta \approx 23^{\circ}$ and $43^{\circ}$, respectively, which are characteristic of amorphous carbon. ${ }^{31}$ These two peaks were also present in the patterns of all of the metal-oxideloaded AC samples, indicating retention of the amorphous structure of AC in the modified AC catalysts. The pattern for 


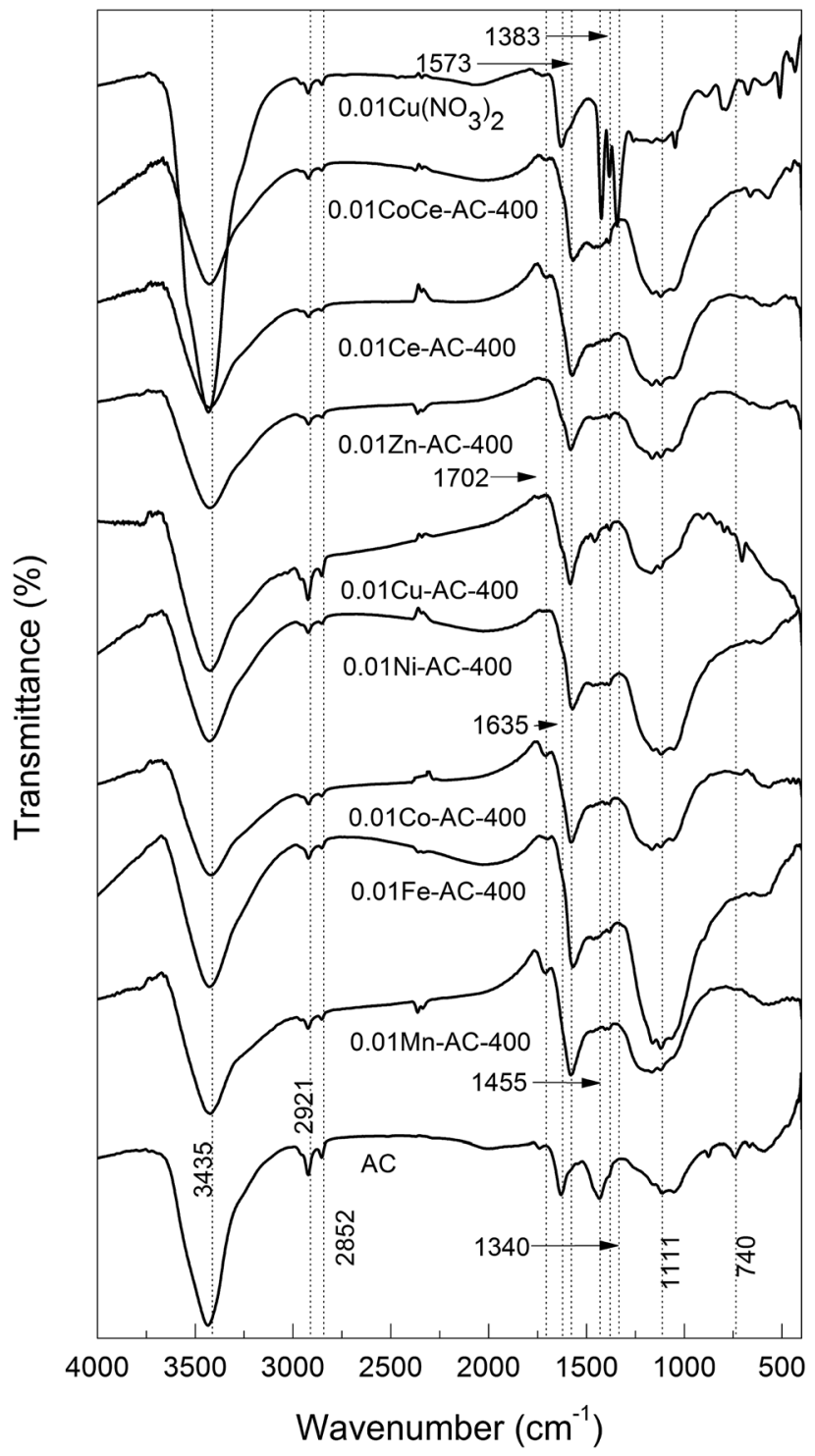

Fig. 1 FTIR spectra of pristine AC and metal-oxide-loaded samples.

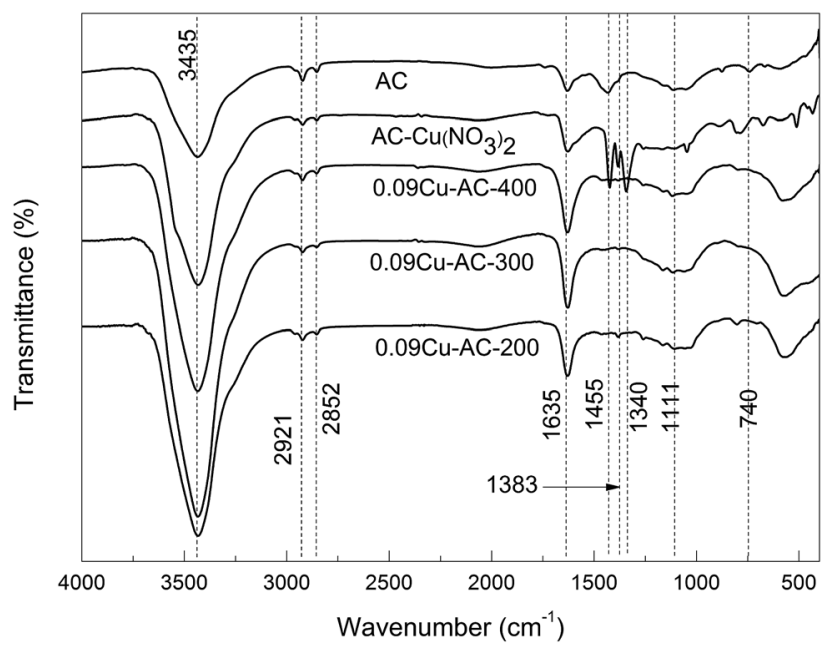

Fig. 2 FTIR spectra of AC with $\mathrm{CuO}$ calcined at different temperatures.

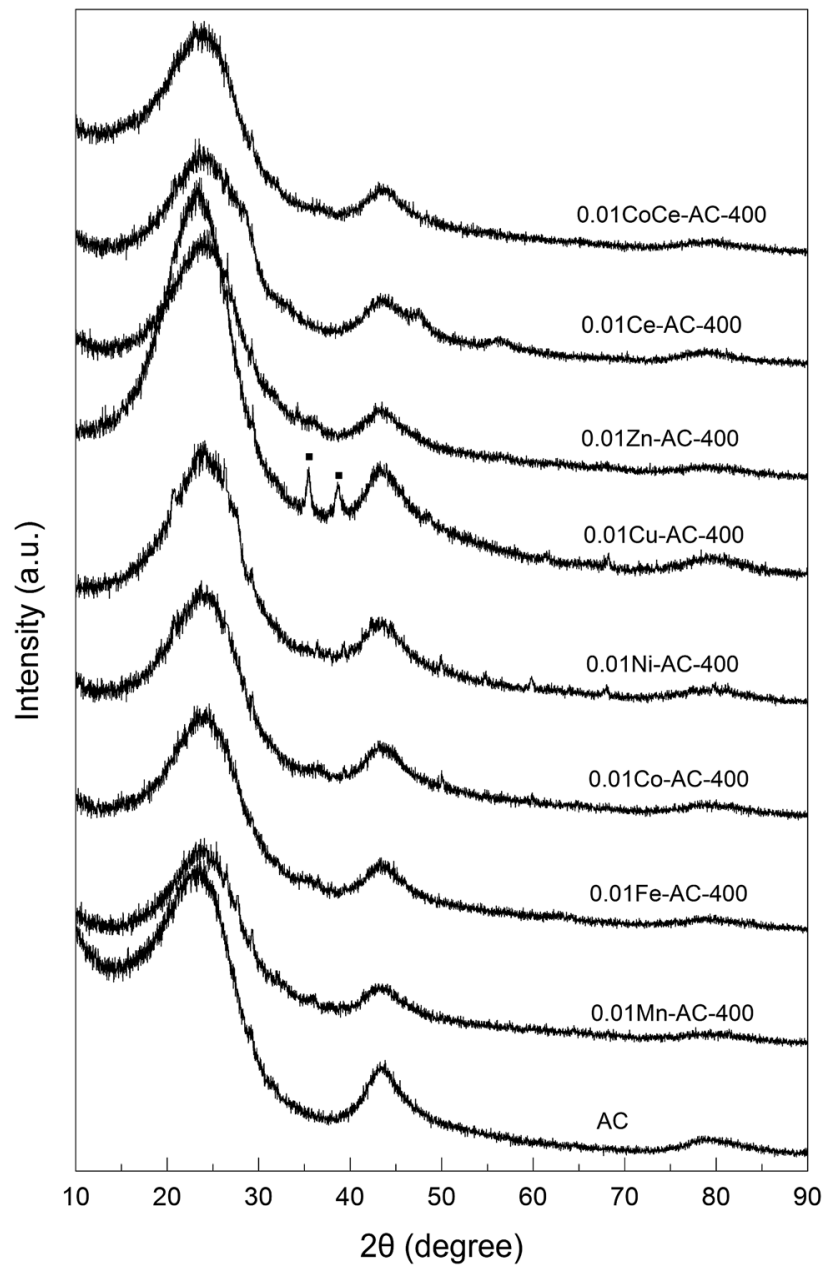

Fig. 3 XRD patterns of pristine AC and metal-oxide-loaded samples.

0.01Cu-AC-400 features two distinct peaks at $35^{\circ}$ and $38^{\circ}$, which can be ascribed to $\mathrm{CuO}$ (JCPDS). ${ }^{32}$ Except for $0.01 \mathrm{Cu}-\mathrm{AC}-400$, the diffraction peaks of other metal oxides on the AC samples were virtually unobservable. This may indicate amorphous structures of these metal oxides due to their poor crystallinity at a calcination temperature of $400{ }^{\circ} \mathrm{C}$. Chmielarz et al. studied cobaltcontaining hydrotalcite-like materials, and found that an amorphous structure of the metal oxide was formed when the calcination temperature was $600{ }^{\circ} \mathrm{C}$, but that the crystallinity increased significantly with temperature. ${ }^{33}$ Therefore, the poor crystallinity of some of the present metal oxides on AC may have resulted from the lower calcination temperature.

XRD patterns of the Cu-loaded AC samples calcined at 200, 300 , and $400{ }^{\circ} \mathrm{C}$ are presented in Fig. 4. Several peaks attributable to $\mathrm{CuO}$ and $\mathrm{Cu}_{2} \mathrm{O}$ were observed, ${ }^{32,34}$ and the intensities of these peaks increased steadily with increasing calcination temperature, implying increasing crystallinity of the copper oxides. Additionally, the content of $\mathrm{Cu}_{2} \mathrm{O}$ increased with increasing calcination temperature, suggesting that a certain amount of $\mathrm{CuO}$ was reduced by $\mathrm{AC}$ at $400{ }^{\circ} \mathrm{C}$.

Thermal analysis. TGA results pertaining to three $0.09 \mathrm{Cu}-\mathrm{AC}$ samples calcined at 200,300 , and $400{ }^{\circ} \mathrm{C}$ are presented in Fig. 5. It can be seen that each of the samples showed a small 


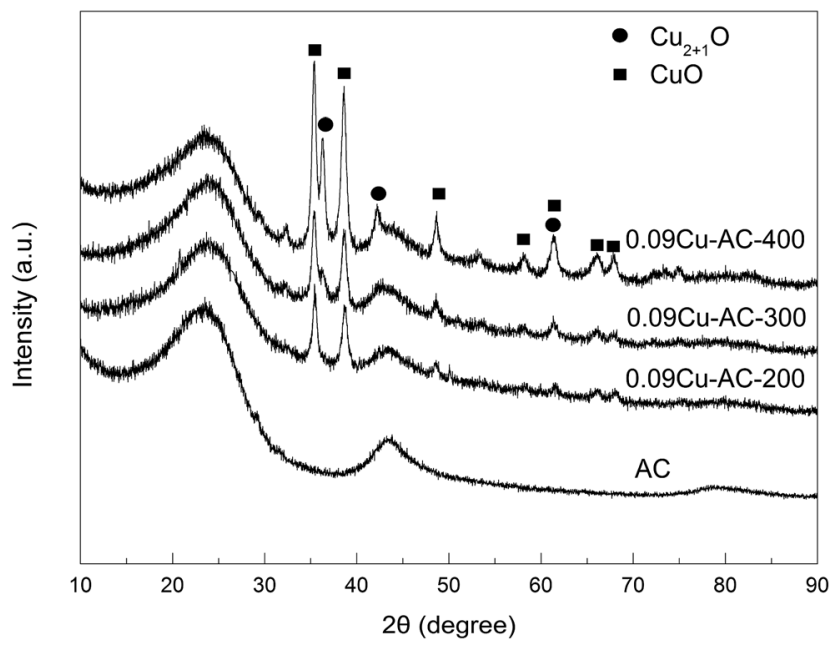

Fig. 4 XRD patterns of $\mathrm{AC}$-supported $\mathrm{CuO}$ calcined at different temperatures $\left(\mathrm{Cu}_{2+1} \mathrm{O}\right.$ is a crystal mixture of $\mathrm{CuO}$ and $\left.\mathrm{Cu}_{2} \mathrm{O}\right)$.

peak before $100{ }^{\circ} \mathrm{C}$ due to the evaporation of water. Based on the derivative weight curves, the initiating temperatures of carbon oxidation by air are about 280,335 , and $375^{\circ} \mathrm{C}$ for $0.09 \mathrm{Cu}-\mathrm{AC}-200$, $0.09 \mathrm{Cu}-\mathrm{AC}-300$, and $0.09 \mathrm{Cu}-\mathrm{AC}-400$, respectively, and the corresponding temperatures for complete carbon oxidation are about 522,587 , and $607^{\circ} \mathrm{C}$. The reactivity of the metal-oxide-loaded carbon samples decreases with increasing calcination temperature for the Cu-loaded AC catalysts, which may be attributed to the decreasing accessibility of carbon to oxygen due to the blanketing effect of the well-developed metal oxide crystalline layer on the surface of the AC. The results also indicate that AC can also be oxidized by the coexistent $\mathrm{O}_{2}$ in the gas stream at about $375{ }^{\circ} \mathrm{C}$, indicating that the coexistent $\mathrm{O}_{2}$ may impose a negative influence on the reduction of $\mathrm{N}_{2} \mathrm{O}$, as discussed latter.

\subsection{Comparison of catalytic activities of different metal oxides}

The catalytic activities of different metal oxides were evaluated in the tubular reactor using $2 \mathrm{~g}$ of each catalyst at a gas flow rate of $100 \mathrm{~mL} \mathrm{~min}^{-1}$, and the results are shown in Table 1. It can be seen that $\mathrm{N}_{2} \mathrm{O}$ was not decomposed over the pristine $\mathrm{AC}$ below $350^{\circ} \mathrm{C}$, but its decomposition increased significantly with increasing temperature. For example, the conversion of $\mathrm{N}_{2} \mathrm{O}$ increased drastically from $6 \%$ at $400{ }^{\circ} \mathrm{C}$ to $100 \%$ at $550{ }^{\circ} \mathrm{C}$. Moreover, different metal oxides exhibited different activities for the conversion of $\mathrm{N}_{2} \mathrm{O}$. Specifically, 0.01Cu-AC- 400 and $0.01 \mathrm{Ni}-\mathrm{AC}-400$ completely removed $\mathrm{N}_{2} \mathrm{O}$ at $400{ }^{\circ} \mathrm{C}$ and $450{ }^{\circ} \mathrm{C}$, respectively. The products were exclusively $\mathrm{N}_{2}$ and $\mathrm{CO}_{2}$, as befits the occurrence of the redox reaction between $\mathrm{AC}$ and $\mathrm{N}_{2} \mathrm{O}$ according to eqn (1):

$$
2 \mathrm{~N}_{2} \mathrm{O}+\mathrm{C}=2 \mathrm{~N}_{2}+\mathrm{CO}_{2}
$$

As evidenced by the FTIR and XRD results, the major difference between the catalysts lay in the loaded metal species, while the structure of the AC remained essentially the same. Therefore, the reactivity differences of the catalysts can be mainly attributed

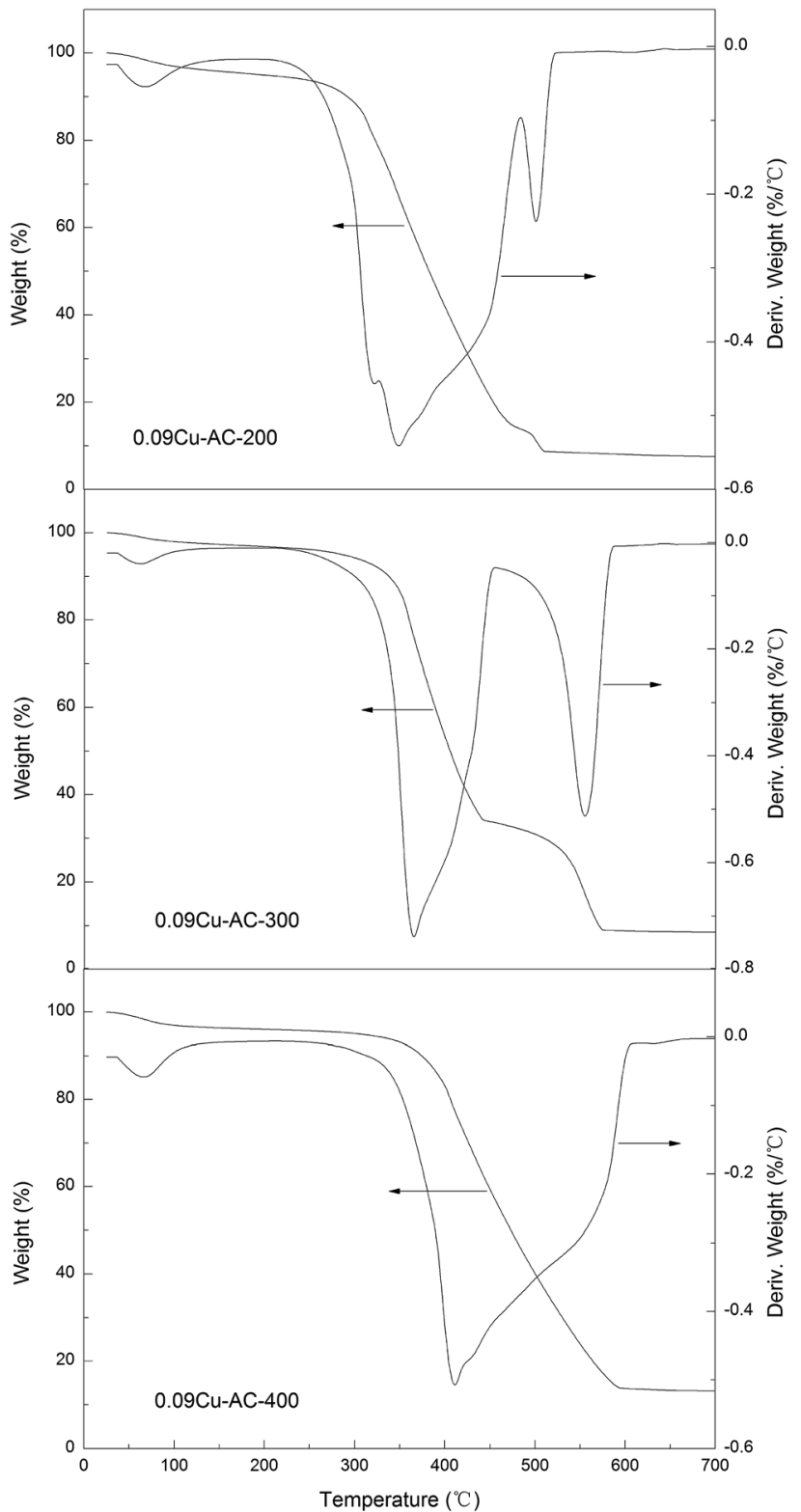

Fig. 5 TGA curves of $\mathrm{AC}$-supported $\mathrm{CuO}$ calcined at $200{ }^{\circ} \mathrm{C}, 300^{\circ} \mathrm{C}$, and $400^{\circ} \mathrm{C}$.

to the different activities of the supported metal oxides for the redox reaction of $\mathrm{AC}$ and $\mathrm{N}_{2} \mathrm{O}$. The catalytic activities decreased in the order $\mathrm{Cu}>\mathrm{Co}>\mathrm{Ni}>\mathrm{Fe}>\mathrm{Mn}>\mathrm{Ce}>\mathrm{Zn}$. This order conforms to that reported by Campa et al. for the reductive removal of $\mathrm{N}_{2} \mathrm{O}$ with $\mathrm{CH}_{4}$, where the order was $\mathrm{Cu}>\mathrm{Co}>\mathrm{Mn} .^{35}$ Therefore, $0.01 \mathrm{Cu}$ AC-400 proved to be the most active catalyst for $\mathrm{N}_{2} \mathrm{O}$ removal among all those studied, and was deemed worthy of further study.

\subsection{Reactivity of Cu-based ACs under varying conditions}

Effect of Cu loading on the catalytic activity. As shown in Fig. 6, the $\mathrm{Cu}$ loading had a significant impact on the removal of $\mathrm{N}_{2} \mathrm{O}$. The complete decomposition temperature of $\mathrm{N}_{2} \mathrm{O}$ decreased greatly with increasing $\mathrm{Cu}$ loading, e.g., from $450{ }^{\circ} \mathrm{C}$ to $325{ }^{\circ} \mathrm{C}$ as the $\mathrm{Cu}$ loading was increased from $0.1 \mathrm{wt} \%$ to 9 
Table 1 Dependence of conversion of $\mathrm{N}_{2} \mathrm{O}$ on temperature

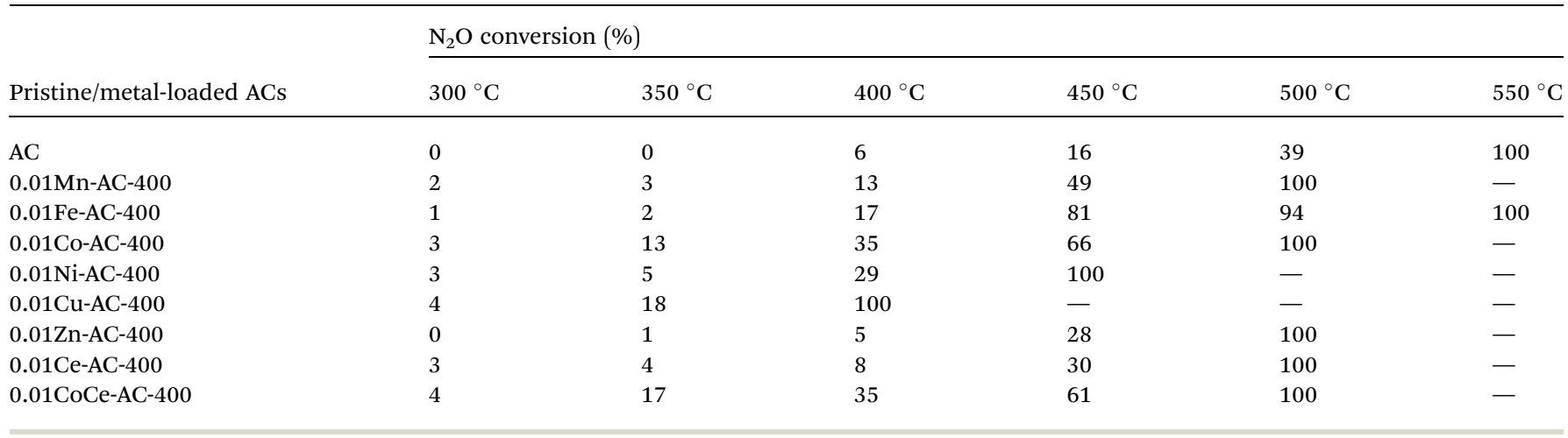

wt $\%$. At any given temperature, e.g. $300{ }^{\circ} \mathrm{C}$, the conversion increased with increasing $\mathrm{Cu}$ loading up to $9 \mathrm{wt} \%$, beyond which the Cu loading had little further influence on the activity. Therefore, the optimal $\mathrm{Cu}$ loading was determined as $9 \mathrm{wt} \%$.

Effect of calcination temperature. Three Cu-loaded AC samples with different calcination temperatures $(200,300$, and $400{ }^{\circ} \mathrm{C}$ ) were prepared, namely 0.09Cu-AC-200, 0.09Cu-AC-300, and $0.09 \mathrm{Cu}-\mathrm{AC}-400$, and their catalytic performances are compared in Fig. 7. Evidently, the calcination temperature had a significant effect on the catalytic reduction of $\mathrm{N}_{2} \mathrm{O}$, and a higher calcination temperature was unfavorable for the catalytic reaction of $\mathrm{AC}$ and $\mathrm{N}_{2} \mathrm{O}$. Specifically, the complete removal temperature of $\mathrm{N}_{2} \mathrm{O}$ increased steadily from $275{ }^{\circ} \mathrm{C}$ for $0.09 \mathrm{Cu}$ AC-200, to $300{ }^{\circ} \mathrm{C}$ for $0.09 \mathrm{Cu}-\mathrm{AC}-300$, and to $325{ }^{\circ} \mathrm{C}$ for 0.09Cu-AC-400. This phenomenon has also been observed by Chmielarz et al. ${ }^{33}$ who ascribed it to the changing crystal form and the decreasing surface area with increasing calcination temperature. This explanation is consistent with the increasing crystallinity of copper oxides for 0.09Cu-AC-200, 0.09Cu-AC-300, and $0.09 \mathrm{Cu}-\mathrm{AC}-400$, as evidenced by the XRD patterns in Fig. 4.

Effect of gas flow rate. The influence of gas flow on the $\mathrm{N}_{2} \mathrm{O}$ removal efficiency was studied for $0.09 \mathrm{Cu}-\mathrm{AC}-400$ at three different flow rates, namely 50, 100, and $150 \mathrm{~mL} \mathrm{~min}^{-1}$, corresponding to GHSV (gas hourly space velocity; ratio of flow rate of

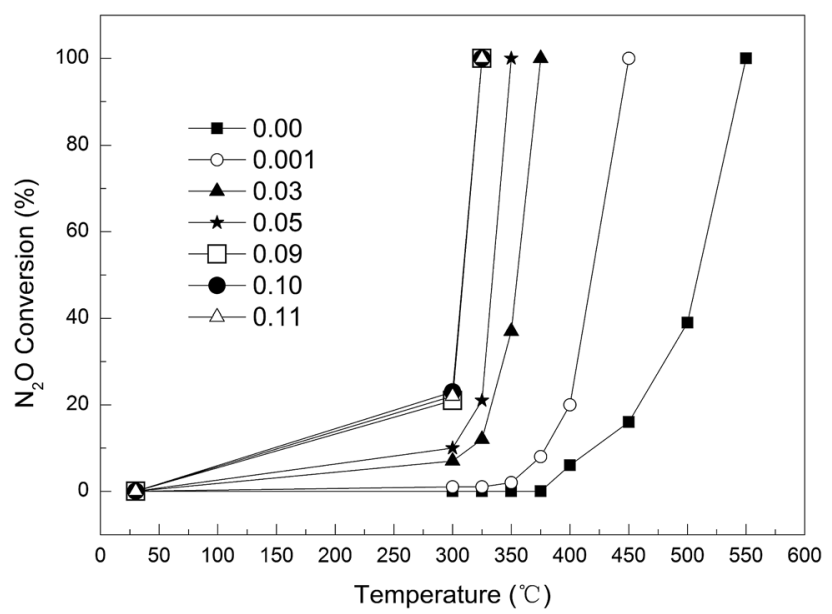

Fig. 6 Effect of $\mathrm{Cu}$ loading on $\mathrm{N}_{2} \mathrm{O}$ conversion.
$\mathrm{N}_{2} \mathrm{O}$ and effective volume of reactor) values of 764.4, 1528.8, and $2293.2 \mathrm{~h}^{-1}$. The results are plotted in Fig. 8. At a lower reaction temperature of $300{ }^{\circ} \mathrm{C}$, the conversion rate of $\mathrm{N}_{2} \mathrm{O}$ decreased with increasing gas flow rate, being restricted by the reaction kinetics. The conversion rates of $\mathrm{N}_{2} \mathrm{O}$ at the above flow rates were $22 \%$, $21 \%$, and $12 \%$, respectively. However, when the temperature was increased to $325^{\circ} \mathrm{C}$, the conversion rate of $\mathrm{N}_{2} \mathrm{O}$ surged to $100 \%$ at gas flow rates of 100 and $150 \mathrm{~mL} \mathrm{~min}^{-1}$, but the $\mathrm{N}_{2} \mathrm{O}$ conversion

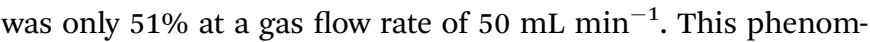
enon could be attributed to the exothermic nature of the reaction and the fast reaction kinetics at a higher temperature. As the flow rate of $\mathrm{N}_{2} \mathrm{O}$ is increased, more reaction heat is released due to the efficient oxidation of carbon by $\mathrm{N}_{2} \mathrm{O}$, which raises the temperature of the AC, and thereby accelerates the reaction dramatically. On the other hand, increasing gas flow rate can shorten the retention time, and thus result in incomplete reduction of $\mathrm{N}_{2} \mathrm{O}$. Therefore, the reaction temperature and retention time synergistically determine the effect of flow rate on $\mathrm{N}_{2} \mathrm{O}$ conversion. The appropriate GHSV was identified as $2293.2 \mathrm{~h}^{-1}$.

\subsection{Catalytic mechanism}

The decomposition process of $\mathrm{N}_{2} \mathrm{O}$ is believed to involve its redox reaction with carbon under catalysis by the loaded metal

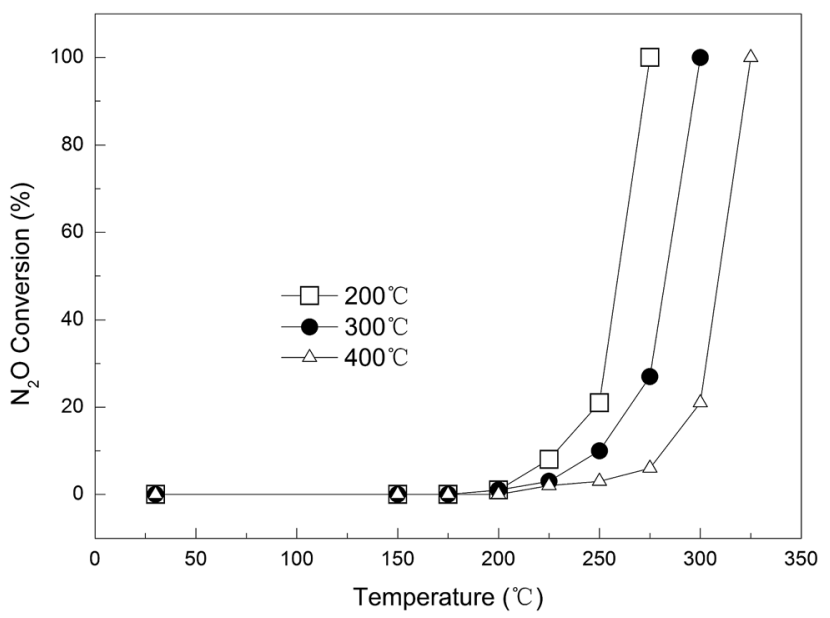

Fig. 7 Dependence of $\mathrm{N}_{2} \mathrm{O}$ conversion on calcination temperature. 


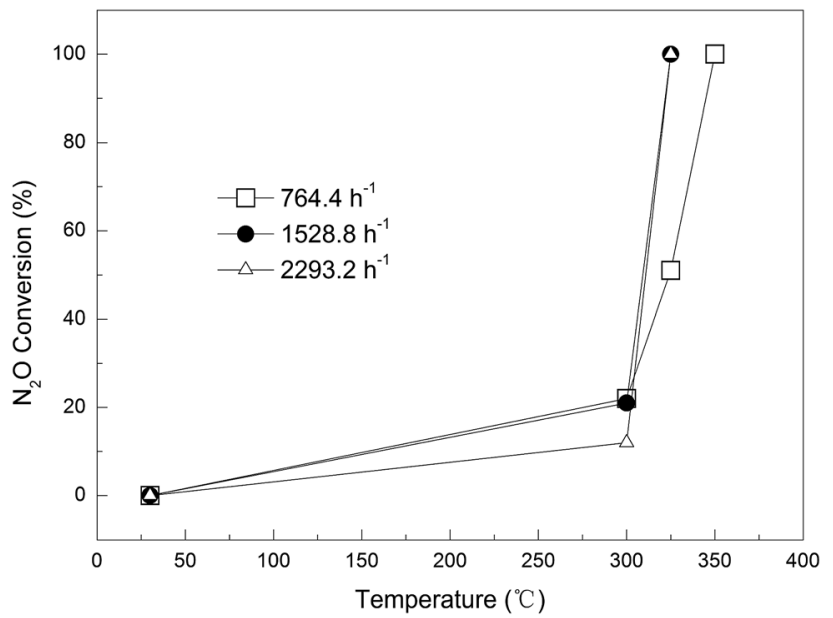

Fig. 8 Effect of gas flow rate on $\mathrm{N}_{2} \mathrm{O}$ conversion.

oxide, as is manifested by the consumption of $\mathrm{AC}$ and the presence of $\mathrm{CO}_{2}$ in the gas effluent. However, this process may be achieved in two different ways, i.e., catalytic decomposition of $\mathrm{N}_{2} \mathrm{O}$, forming $\mathrm{O}_{2}$ and in situ oxidation therewith of the carbon support, or reduction of copper oxides by carbon to $\mathrm{Cu}$ metal, followed by the in situ oxidation of $\mathrm{Cu}$ by $\mathrm{N}_{2} \mathrm{O}$. To identify the reaction mechanism, we studied the XPS patterns of three different reagents, namely, the original reactant (OR, $0.03 \mathrm{Cu}-\mathrm{AC}-200$ ), the nitrogen-treated reactant (NTR, obtained by heating $\mathrm{OR}$ at $400{ }^{\circ} \mathrm{C}$ in $\mathrm{N}_{2}$ for $5 \mathrm{~h}$ ), and the used reactant

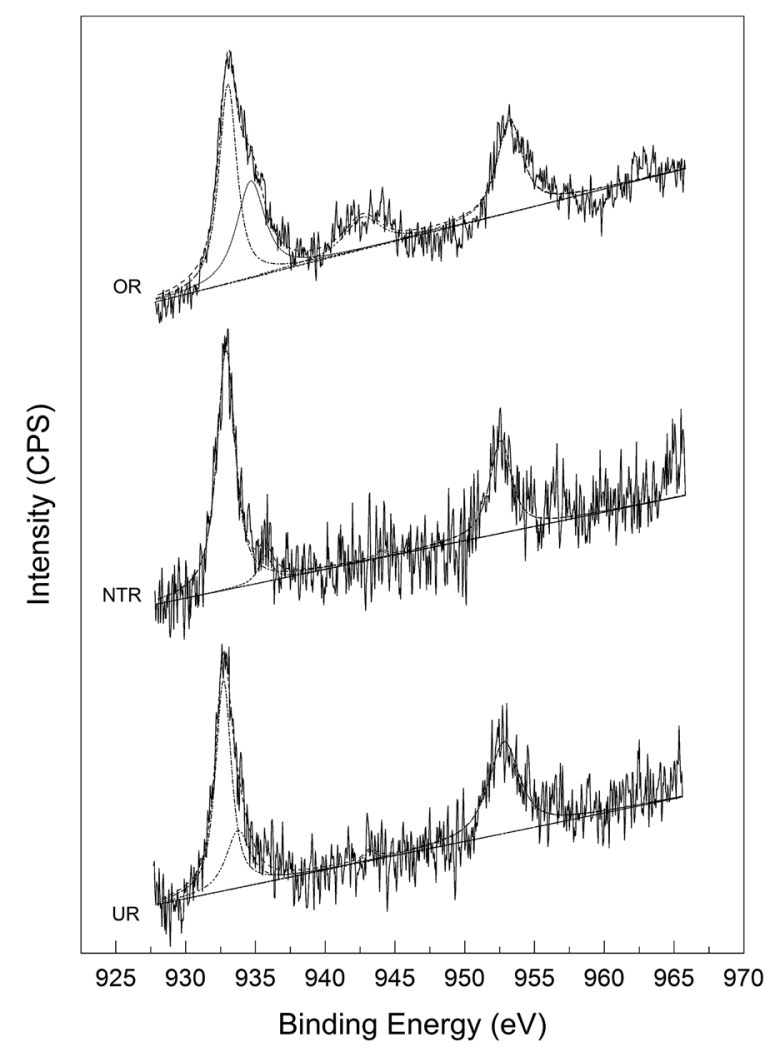

Fig. 9 Cu 2p XPS patterns of OR, NTR, and UR.
(UR, obtained by heating the NTR at $400{ }^{\circ} \mathrm{C}$ in $\mathrm{N}_{2} \mathrm{O}$ for $2 \mathrm{~h}$ ). Fig. 9 shows the $\mathrm{Cu} 2 \mathrm{p}$ XPS spectra.

As can be seen from the XPS spectra, the primary and shoulder peaks appear at binding energies (B.E.) of around 933 and $943 \mathrm{eV}$, respectively, for $\mathrm{Cu} 2 \mathrm{p}_{3 / 2}$. As shown in Table 2, the B.E. values of the primary peaks for NTR and UR were slightly lower than that for OR, implying a lower valence of $\mathrm{Cu}$ in NTR and UR. This might be attributed to the reduction of $\mathrm{CuO}$ by carbon at a high temperature of $400{ }^{\circ} \mathrm{C}$. All of the samples showed a shake-up satellite peak at around $943 \mathrm{eV}$, which is characteristic of $\mathrm{Cu}^{2+}$. Meanwhile, the weakened satellite peaks for NTR and UR imply decreased amounts of $\mathrm{Cu}^{2+}$ and increased amounts of $\mathrm{Cu}^{+}$or $\mathrm{Cu}^{0}$ therein. The intensity ratios of the satellite and primary peaks for $\mathrm{Cu} 2 \mathrm{p}_{3 / 2}$ are shown in Table 2. This ratio is about 0.55 for standard $\mathrm{CuO}$ and 0 for a $\mathrm{Cu}^{0}$ phase. ${ }^{36}$ As can be seen in Table 2, NTR showed the lowest valence of $\mathrm{Cu}$, UR showed a slightly higher valence, and OR showed the highest valence.

In addition to the XPS results, the above samples were also analyzed by XRD. As is evident from Fig. 10, CuO peaks were only seen for OR; they were no longer seen for NTR due to complete conversion to $\mathrm{Cu}_{2} \mathrm{O}$ and $\mathrm{Cu}$. Supposedly, at a high temperature of $400{ }^{\circ} \mathrm{C}$ under nitrogen, the $\mathrm{CuO}$ component in the OR sample was successively reduced by $\mathrm{AC}$ to $\mathrm{Cu}_{2} \mathrm{O}$ and $\mathrm{Cu}$, such that the amount of $\mathrm{Cu}$ became dominant. In contrast, only $\mathrm{CuO}$ and $\mathrm{Cu}_{2} \mathrm{O}$ were found in UR, and no elemental $\mathrm{Cu}$ could be detected. This may be the net result of the oxidation of $\mathrm{Cu}$ by $\mathrm{N}_{2} \mathrm{O}$ and the reduction of $\mathrm{CuO}$ by carbon when NTR was heated to $400{ }^{\circ} \mathrm{C}$ in $\mathrm{N}_{2} \mathrm{O}$ atmosphere. This phenomenon is consistent with earlier investigations by Carabineiro et al., ${ }^{37,38}$ and $\mathrm{Zhu}$ et al. ${ }^{19}$

Based on our experimental evidence and above analysis, the catalytic mechanism of $\mathrm{CuO}$ for the reductive removal of $\mathrm{N}_{2} \mathrm{O}$ by $\mathrm{AC}$ is assumed to proceed as follows:

$$
\begin{gathered}
4 \mathrm{CuO}+\mathrm{C} \rightarrow 2 \mathrm{Cu}_{2} \mathrm{O}+\mathrm{CO}_{2} \\
2 \mathrm{Cu}_{2} \mathrm{O}+\mathrm{C} \rightarrow 4 \mathrm{Cu}+\mathrm{CO}_{2} \\
2 \mathrm{Cu}+\mathrm{N}_{2} \mathrm{O} \rightarrow \mathrm{Cu}_{2} \mathrm{O}+\mathrm{N}_{2} \\
\mathrm{Cu}_{2} \mathrm{O}+\mathrm{N}_{2} \mathrm{O} \rightarrow 2 \mathrm{CuO}+\mathrm{N}_{2}
\end{gathered}
$$

In this process, $\mathrm{CuO}$ is involved in transfer of the $\mathrm{O}$ atom from $\mathrm{N}_{2} \mathrm{O}$ to carbon, accelerating the overall redox reaction between $\mathrm{N}_{2} \mathrm{O}$ and AC. In short, $\mathrm{AC}$ in the present process serves

Table 2 Cu 2p high-resolution XPS spectra

\begin{tabular}{lllll}
\hline Sample & $\begin{array}{l}\mathrm{Cu} 2 \mathrm{p}_{3 / 2} \\
\mathrm{mp}^{a} \text { B.E. }\end{array}$ & $\begin{array}{l}\mathrm{Cu}^{2} \mathrm{p}_{3 / 2} \\
\mathrm{sp}^{b} \text { B.E. }\end{array}$ & $\begin{array}{l}\text { Splitting energy }^{c} \\
(\mathrm{eV})\end{array}$ & $I_{\mathrm{sp}} / I_{\mathrm{mp}}{ }^{d}$ \\
\hline OR & 933.1 & 942.7 & 9.6 & 0.21 \\
NTR & 932.9 & 944.0 & 11.1 & 0.03 \\
UR & 932.7 & 943.3 & 10.6 & 0.04
\end{tabular}

$a$ "mp" denotes the main peak. ${ }^{b}$ "sp" denotes the shake-up satellite peak. "splitting energy" is the energy difference between mp and sp. $d$ " $I_{\mathrm{sp}} / I_{\mathrm{mp}}$ " is the intensity ratio of $\mathrm{sp}$ and $\mathrm{mp}$. 


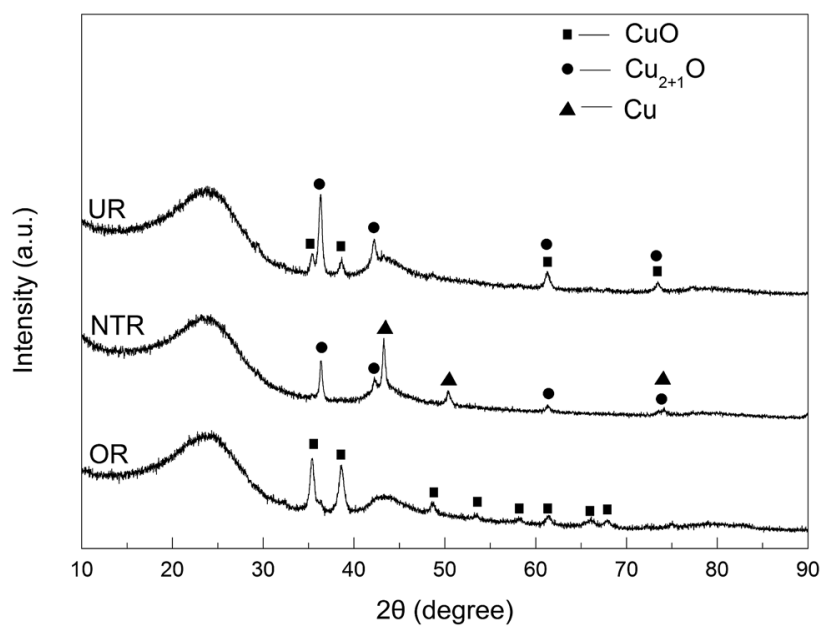

Fig. 10 XRD patterns of loaded ACs in different statuses.

as a consumptive solid reductant for reducing $\mathrm{N}_{2} \mathrm{O}$ to nitrogen, while $\mathrm{CuO}$ functions as a catalyst for the reaction between $\mathrm{N}_{2} \mathrm{O}$ and carbon.

\subsection{Applicability and challenge of the present process}

Catalytic reduction of $\mathrm{N}_{2} \mathrm{O}$ may be achieved at mild conditions by using AC as solid reducing agent and $\mathrm{CuO}$ as catalyst. This process is especially suitable for the treatment of tail gas of the adipic acid production process with high concentration of $\mathrm{N}_{2} \mathrm{O}$, and is advantageous due to its safety, ease of control, low operating temperature $\left(300-400{ }^{\circ} \mathrm{C}\right)$, and lower cost of AC. And even the industrial waste $\mathrm{AC}$ may be also applicable, which further reduces the raw material cost and makes a resource use of another industrial waste. However, some challenges should be considered and tackled properly, e.g. competitive oxidation of $\mathrm{O}_{2}$ with $\mathrm{N}_{2} \mathrm{O}$ and emission of toxic metal oxide nanoparticles from the exhaust gas. In fact, such competitive oxidation is inevitable in all reductive removal processes of $\mathrm{N}_{2} \mathrm{O}$ with varying reducing agents, such as $\mathrm{H}_{2}, \mathrm{CO}$, and $\mathrm{CH}_{4}$. However, the reactivity of $\mathrm{N}_{2} \mathrm{O}$ with $\mathrm{AC}$ is higher than that of $\mathrm{O}_{2}$, as manifested by its lower reaction temperature on $0.09 \mathrm{Cu}-\mathrm{AC}-400$, i.e. $300{ }^{\circ} \mathrm{C}$ for $\mathrm{N}_{2} \mathrm{O}$ (Fig. 6) and about $375^{\circ} \mathrm{C}$ for air $\left(\mathrm{O}_{2}\right)$ (Fig. 5). Therefore, the inhibition effect of $\mathrm{O}_{2}$ for the reduction of $\mathrm{N}_{2} \mathrm{O}$ may be quite low at appropriate conditions, for example, the presence of $\mathrm{O}_{2}$ was found to have no influence on the $\mathrm{N}_{2} \mathrm{O}$-char reactivity at higher temperature..$^{39,40}$ In contrast, at lower temperature of $320^{\circ} \mathrm{C}$ and lower $\mathrm{N}_{2} \mathrm{O}$ content $\left(0.3 \% \mathrm{~N}_{2} \mathrm{O}\right.$ in helium gas), the coexistent $1.5 \% \mathrm{O}_{2}$ may lead to a $20 \%$ lowering of reactivity of $\mathrm{N}_{2} \mathrm{O}$ on $\mathrm{Cu}_{2} \mathrm{O}$-AC catalyst ${ }^{25}$ due to the blocking effect of $\mathrm{O}_{2}$ for the active sites of AC. ${ }^{26}$ As a reducing agent, AC will be oxidized and consumed gradually, and the residue toxic metal oxides may be emitted from the exhaust gas to the atmosphere. However, this problem may be solved through conventional technical approaches. For example, by using a moving-bed reactor, most of the ultrafine metal oxide particles will be retained in the reactor due to the filtering effect of the granular AC catalyst, some of the particles can be collected as sediment in the baffled heat exchanger for cooling the high temperature exhaust gas to ambient temperature, and finally, the ultrafine ashes can be further removed to reach the environmental standard by wet or electrostatic dust collector.

\section{Conclusions}

$\mathrm{N}_{2} \mathrm{O}$ can be completely decomposed by $\mathrm{AC}$ at $550{ }^{\circ} \mathrm{C}$ through a redox reaction between $\mathrm{AC}$ as reductant and $\mathrm{N}_{2} \mathrm{O}$ as oxidant. The decomposition reaction is greatly enhanced by some transition metal oxide catalysts, among which $\mathrm{CuO}$ has proved to be the best one. Complete removal of $\mathrm{N}_{2} \mathrm{O}$ was achieved by $0.09 \mathrm{Cu}$ AC-200 at a much lower temperature of $275{ }^{\circ} \mathrm{C}$. The catalytic mechanism of CuO has been studied by XPS and XRD, which would seem to involve the reduction of $\mathrm{CuO}$ to $\mathrm{Cu}_{2} \mathrm{O}$ and $\mathrm{Cu}$ by $\mathrm{AC}$, and oxidation of $\mathrm{Cu}$ to $\mathrm{Cu}_{2} \mathrm{O}$ and $\mathrm{CuO}$ by $\mathrm{N}_{2} \mathrm{O}$. In this process, $\mathrm{CuO}$ is involved in transfer of the $\mathrm{O}$ atom from $\mathrm{N}_{2} \mathrm{O}$ to carbon, accelerating the overall redox reaction between $\mathrm{N}_{2} \mathrm{O}$ and AC.

\section{References}

1 M. A. Zamudio, S. Bensaid, D. Fino and N. Russo, Ind. Eng. Chem. Res., 2011, 50, 2622-2627.

2 N. Li, Chem. Ind. Eng. Prog., 2007, 26, 1659-1661.

3 Y. Shen, C. Li, Y. Tang and S. Zhu, RSC Adv., 2015, 5, 1321213219.

4 S. Kannan, Appl. Clay Sci., 1998, 13, 347-362.

5 J. K. Lee, Y. J. Kim, H. J. Lee, S. H. Kim, S. J. Cho, I. S. Nam and S. B. Hong, J. Catal., 2011, 284, 23-33.

6 B. M. Abu-Zied, Microporous Mesoporous Mater., 2011, 139, 59-66.

7 B. H. Chen, N. Liu, X. Y. Liu, R. D. Zhang, Y. P. Li, Y. X. Li and X. L. Sun, Catal. Today, 2011, 175, 245-255.

8 T. P. Gaidey, Russ. J. Appl. Chem., 2009, 82, 1689-1705.

9 V. G. Komvokis, M. Marti, A. Delimitis, I. A. Vasalos and K. S. Triantafyllidis, Appl. Catal., B, 2011, 103, 62-71.

10 S. S. Kim, S. J. Lee and S. C. Hong, Chem. Eng. J., 2011, 169, 173-179.

11 M. Hussain, D. Fino and N. Russo, J. Hazard. Mater., 2012, 211, 255-265.

12 Q. Zhang, X. Tang, P. Ning, Y. Duan, Z. Song and Y. Shi, RSC Adv., 2015, 5, 51263-51270.

13 C. Li, Y. Shen, S. Zhu and S. Shen, RSC Adv., 2014, 4, 2910729119.

14 T. Xu, C. Wang, X. Wu, B. Zhao, Z. Chen and D. Weng, RSC Adv., 2016, 6, 97004-97011.

15 M. Mihet, V.-M. Cristea, P.-S. Agachi, A.-M. Cormos and M. D. Lazar, $R S C A d v .$, 2016, 6, 89259-89273.

16 P. Nematollahia and M. D. Esrafili, RSC Adv., 2016, 6, 5909159099.

17 J. Rodriguez-Mirasol, A. C. Ooms, J. R. Pels, F. Kapteijn and J. A. Moulijn, Combust. Flame, 1994, 99, 499-507.

18 Z. H. Zhu and G. Q. Lu, J. Catal., 1999, 187, 262-274.

19 Z. H. Zhu, G. Q. Lu and R. T. Yang, J. Catal., 2000, 192, 77-87.

20 F. Gonçalves and J. L. Figueiredo, Appl. Catal., B, 2004, 50, 271-278. 
21 F. Gonçalves and J. L. Figueiredo, Appl. Catal., B, 2006, 62, 181-192.

22 Y. Chen, Z. Hu, X. Wang, G. Zhao, Y. Liu and W. Liu, Acta Phys.-Chim. Sin., 2008, 249, 1589-1596.

23 J. Sun, H. Wang and B. Sun, Chin. J. Environ. Eng., 2011, 5, 261-266.

24 C. Wang, Y. Liu, X. Zheng, Z. Wen, A. Liu, X. Xu and Z. Hu, Gongneng Cailiao, 2010, 9, 1520-1528.

25 Z. H. Zhu, L. R. Radovic and G. Q. Lu, Carbon, 2000, 38, 451464.

26 Y. H. Li, G. Q. Lu and V. Rudolph, Chem. Eng. Sci., 1998, 53, $1-26$.

27 S. A. Carabineiro, F. B. Fernandes, A. M. Ramos, J. Vital and I. F. Silva, Catal. Today, 2000, 57, 305-312.

28 A. N. Zhou, X. L. Ma and C. S. Song, Appl. Catal., B, 2009, 87, 190-199.

29 Y. F. Jia and K. M. Thomas, Langmuir, 2000, 16, 1114-1122. 30 B. H. Stuart, Infrared Spectroscopy: Fundamentals and Applications, Wiley, 2004.

31 W. N. R. W. Isahak, M. W. M. Hisham and M. A. Yarmo, J. Chem., 2013, 2013, 1-6.
32 J. Co, P. D. Standards, Powder Diffraction File, ASTM, Newtown Square, PA, USA, 2004, pp. 48-1548.

33 L. Chmielarz, M. Rutkowska, P. Kuśtrowski, M. Drozdek, Z. Piwowarska, B. Dudek, R. Dziembaj and M. Michalik, J. Therm. Anal. Calorim., 2011, 105, 161-170.

34 J. Co, P. D. Standards, Powder Diffraction File, ASTM, Newtown Square, PA, USA, 2004, pp. 05-0667.

35 M. C. Campa, V. Indovina and D. Pietrogiacomi, Appl. Catal., $B, 2012$, 111, 90-95.

36 A. Patel, P. Shukla, T. Rufford, S. Wang, J. Chen, V. Rudolph and Z. H. Zhu, Appl. Catal., A, 2011, 409, 55-65.

37 S. A. Carabineiro, F. B. Fernandes, R. J. C. Silva, J. S. Vital, A. M. Ramos and I. M. Fonseca, Catal. Today, 2008, 133, 441-447.

38 S. A. Carabineiro, F. B. Fernandes, J. S. Vital, A. M. Ramos and I. M. Fonseca, Appl. Catal., B, 2005, 59, 181-186.

39 I. Gulyurtlu, H. Esparteiro and I. Cabrita, Fuel, 1994, 73, 1098-1102.

40 J. Rodriguez-Mirasol, A. C. Ooms, J. R. Pels, F. Kapteijn and J. A. Moulijn, Combust. Flame, 1994, 99, 499-507. 